\begin{tabular}{|c|c|}
\hline Title & Electrochromism of Niobium Oxide Thin Films Prepared by the Sol-Gel Process \\
\hline Author(s) & Ohtani, B.; Iwai, K.; Nishimoto, S-i; Inui, T. \\
\hline Citation & $\begin{array}{l}\text { Journal of the Electrochemical Society, 141(9), 2439-2442 } \\
\text { https://doi.org/10.1149/1.2055139 }\end{array}$ \\
\hline Issue Date & 1994 \\
\hline Doc URL & http:/hdl.handle.net/2115/57982 \\
\hline Rights & $\begin{array}{l}\text { (1) The Electrochemical Society, Inc. 1994. All rights reserved. Except as provided under U.S. copyright law, this work } \\
\text { may not be reproduced, resold, distributed, or modified without the express permission of The Electrochemical Society } \\
\text { (ECS). The archival version of this work was published in J. Electrochem. Soc. 1994 volume 141, issue 9, 2439-2442. }\end{array}$ \\
\hline Type & article \\
\hline File Information & J. Electrochem. Soc.-1994-Ohtani-2439-42.pdf \\
\hline
\end{tabular}

Instructions for use 


\title{
Electrochromism of Niobium Oxide Thin Films Prepared by the Sol-Gel Process
}

\author{
Bunsho Ohtani, Kunihiro Iwai, Sei-ichi Nishimoto, and Tomoyuki Inui \\ Division of Energy and Hydrocarbon Chemistry, Graduate School of Engineering, Kyoto University, Kyoto 606-01, Japan
}

\section{ABSTRACT}

Thin layers of niobium oxide $\left(\mathrm{NbO}_{x}\right)$ were accumulated by the sol-gel process, with the sol of $\mathrm{NbO}_{x}$ in ethanol prepared by partial hydrolysis of commercial niobium(V) ethoxide, on glass plates coated with transparent conducting tin oxide. Characterization by x-ray diffraction, differential thermal analysis, and thermogravimetry revealed that the as-prepared film, consisting of fully hydrated amorphous niobium(V) oxide, undergoes dehydration into the partially hydrated form and, finally, crystalline niobium $(\mathrm{V})$ oxide $\left(\mathrm{Nb}_{2} \mathrm{O}_{5}\right)$ by calcination at the temperature up to $873 \mathrm{~K}$. The films exhibited electrochromic (EC) properties; the reversible color change was observed between colorless and brown-black by alternating anodic and cathodic polarizations, respectively. Among the films used in this study the crystalline $\mathrm{Nb}_{2} \mathrm{O}_{5}$ film showed the best EC properties and its spectral change, durability for repeated coloration-decoloration cycles, and retentivity of colored states, i.e., memory characteristics under open-circuit conditions were investigated in detail.

Transition metal oxides, e.g., oxides of tungsten $\left(\mathrm{WO}_{3}\right)$, molybdenum $\left(\mathrm{MoO}_{3}\right)$, and vanadium $\left(\mathrm{V}_{2} \mathrm{O}_{5}\right)$, have been extensively investigated as electrochromic devices in the form of a thin film adhering to a conducting substrate. ${ }^{1}$ Among them, niobium oxide $\left(\mathrm{NbO}_{x}\right)$ is also expected to show electrochromism, and several studies on $\mathrm{NbO}_{x}$ thin films prepared by thermal oxidation, ${ }^{2-5}$ anodization, ${ }^{6}$ sputtering, ${ }^{7}$ vacuum evaporation, ${ }^{8}$ and the sol-gel process ${ }^{9}$ have been reported.

Previous work in this laboratory has shown electrochemical response of $\mathrm{WO}_{3},{ }^{10}$ iron(III) oxide $\left(\mathrm{Fe}_{2} \mathrm{O}_{3}\right),{ }^{11}$ and titanium(IV) oxide $\left(\mathrm{TiO}_{2}\right)^{12}$ films prepared by sol-gel process. ${ }^{13}$ In comparison with the sputtering or vacuum evaporation technique, the sol-gel process is of advantage for preparation without using specialized instruments such as a vacuum chamber. The preparation of $\mathrm{NbO}_{x}$ thin film by thermal oxidation and anodization requires the niobium metal plates of desired size and shape of devices. This might be a limitation to these preparation processes. However, the solgel process has no such limitation; it is possible essentially to produce the film on the given substrate material in any size and shape. This paper deals with the preparation of $\mathrm{NbO}_{x}$ thin films by the sol-gel process and the characterization of their properties by x-ray diffraction (XRD), differential thermal analysis (DTA), and thermogravimetry (TG). Their electrochemical (EC) properties are discussed and correlated with the structure.

\section{Experimental}

Sol of $\mathrm{NbO}_{z}$ was prepared by partial hydrolysis of niobi$\mathrm{um}(\mathrm{V})$ ethoxide $\left[\mathrm{Nb}(\mathrm{OEt})_{5}\right]$ (Kanto Chemicals) with concentrated hydrochloric acid ( $\mathrm{HCl}$; Wako Pure Chemical Industries). Griesmar and co-workers have reported the preparation of clear sol and monolithic gel of $\mathrm{NbO}_{x}$ by the hydrolysis of niobium $(\mathrm{V})$ pentoxide $\left[\mathrm{Nb}(\mathrm{OPn})_{5}\right]$ in the presence of acetic acid. ${ }^{14}$ As shown below, however, the addition of $\mathrm{HCl}$ also enables the preparation of clear $\mathrm{NbO}_{x}$ sol. A portion of $\mathrm{Nb}(\mathrm{OEt})_{5}(0.036$ moles $)$ was dissolved in ethanol (Wako, $99.5 \%$, water $0.4 \% ; 1.7$ moles) at room temperature and cooled to $273.5 \mathrm{~K}$ in an ice bath. To the solution was slowly added under stirring a mixture of ethanol $(0.98 \mathrm{~mol})$ and $\mathrm{HCl}(0.038 \mathrm{~mol})$. Additional stirring overnight at room temperature led to a slightly yellow clear sol containing $0.21 \mathrm{~mol} \mathrm{dm}^{-3}$ of $\mathrm{NbO}_{x}$. Glass substrates coated with transparent conducting tin oxide (NESA, $22.3 \Omega / \square$ ) were supplied from Nippon Sheet Glass Company Limited in a cleaned state and used just after removal of dust by the blowing of dry air. The plates were dipped in and drawn from the $\mathrm{NbO}_{x}$ sol at a constant rate of $0.6 \mathrm{~mm} \mathrm{~s}^{-1}$. After gelation at room temperature for $10 \mathrm{~min}$, the coated substrates were calcined at $423 \mathrm{~K}$ for $5 \mathrm{~min}$ in an electric furnace. Further calcination at the higher temperature $\left(T_{c}\right)$ was performed for $2 \mathrm{~h}$ for every ten-layer accumulation. Hereafter, the entry of $\mathrm{NbO}_{x}$ films is made with the number of the layer and $T_{c}, e . g ., 20 / 733$ refers to the film consisting of 20 layers calcined at $733 \mathrm{~K}$.

Electrochemical measurements were performed with an HA-301 potentiostat/galvanostat, an HB-104 function generator, and an HF-202D coulometer (Hokuto Denko). A Pyrex cell with flanges in opposite sides was used. An $\mathrm{NbO}_{x}$-coated substrate and a Pyrex glass plate were fixed on the flanges in parallel each other with fluorinated rubber (Vyton) gaskets. Through these two parallel plates passed the light beam for optical absorption measurements (a Shimadzu UV-200S spectrophotometer). A plane platinum counterelectrode and an $\mathrm{Ag} / \mathrm{AgCl}$ reference electrode were fixed in the positions outside the light beam. Electrolyte solutions, 1.0 or $9.0 \mathrm{~mol} \mathrm{\textrm {dm } ^ { - 3 }}$ aqueous formic acid solution or $0.5 \mathrm{~mol} \mathrm{dm}^{-3}$ sulfuric acid in the cell were deaerated by bubbling nitrogen for at least $20 \mathrm{~min}$ before and during the measurements.

$\mathrm{X}$-ray diffraction patterns of $\mathrm{NbO}_{x}$ films on NESA glass substrate were recorded on a Mac Science MXP18 diffrac-

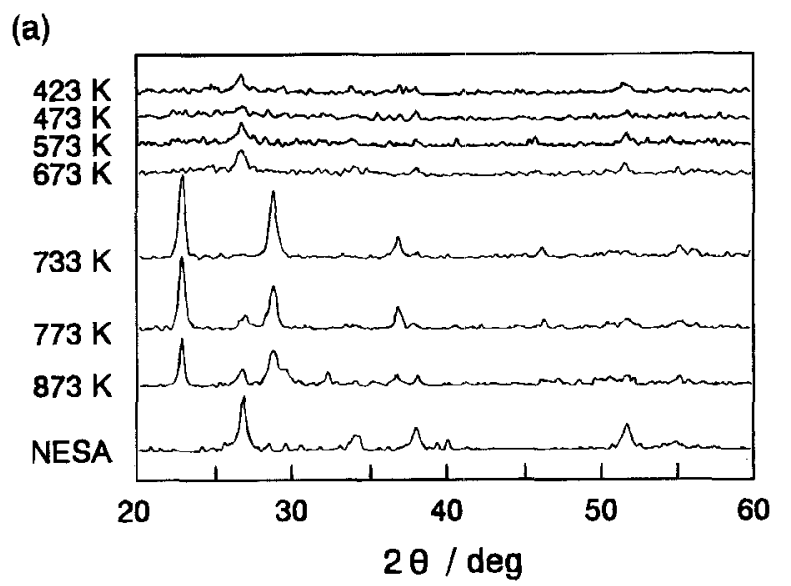

(b)

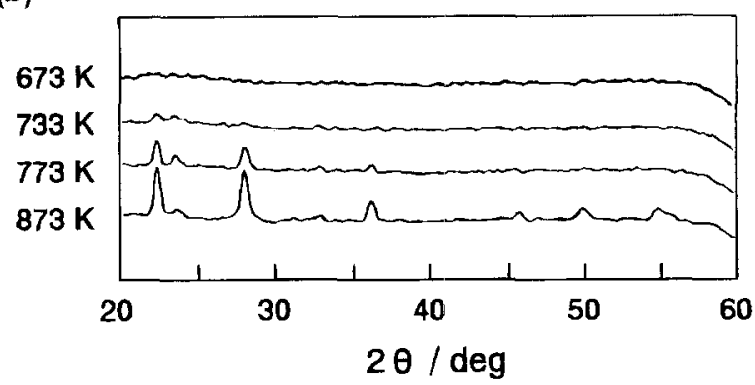

Fig. 1. Parts of XRD patterns of $\mathrm{NbO}_{x}$ in the form of (a) films and (b) powders. 


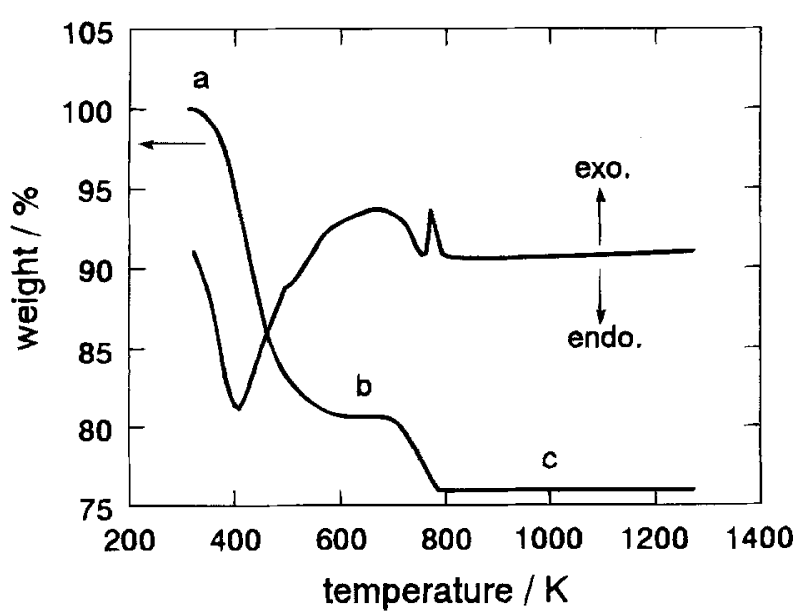

Fig. 2. DTA and TG of $\mathrm{NbO}_{x}$ powder.

tometer $\left(\mathrm{Cu} \mathrm{K}_{\alpha} ; 50 \mathrm{kV}, 200 \mathrm{~mA}\right)$ with a fixed incident angle of $\mathrm{x}$-ray to the films at $0.3 \mathrm{deg} .{ }^{15}$ For comparison, $\mathrm{NbO}_{x}$ powder was prepared by gelation of the sol at ambient temperature, dried at $383 \mathrm{~K}$, and calcined in a furnace of elevated temperature up to $1273 \mathrm{~K}$ at a rate of $20 \mathrm{deg} \mathrm{min}^{-1}$. The powder XRD patterns were measured in situ by a Shimadzu XD-D1 diffractometer ( $\mathrm{Cu} \mathrm{K} ; 40 \mathrm{kV}, 40 \mathrm{~mA}$ ) with conventional scanning procedure. Thermogravimetry (TG) and DTA were performed in air with the temperature range of room temperature to $1273 \mathrm{~K}$ at a heating rate of $10 \mathrm{deg}$ min $^{-1}$ by using a ULVAC HPC-5000 equipped with an infrared image furnace.

\section{Results and Discussion}

Figure 1 shows parts of XRD patterns of $\mathrm{NbO}_{x}$ films (a) and powders (b) prepared by the gelation of $\mathrm{NbO}_{x}$ sol and subsequent heat-treatment. Only less intense peaks corresponding to the NESA layer $(2 \theta ; 27.0,38.0,52.0 \mathrm{deg}) \mathrm{ap}-$ peared in the pattern of films calcined at $<733 \mathrm{~K}$, suggesting their amorphous structure. Similar amorphous structure was observed in the case of powder. Heat-treatment at higher temperatures ( $\geqq 733 \mathrm{~K}$ ) led to the crystallization of $\mathrm{NbO}_{x}$ as seen for both films and powders; intense peaks $(2 \theta ; 22.5,28.0,37.0 \mathrm{deg})$ are assigned to $\mathrm{Nb}_{2} \mathrm{O}_{5}$ crystallites. ${ }^{16}$ The relatively smaller intensity of the powder at $733 \mathrm{~K}$ may be due to the shorter duration ( $5 \mathrm{~min}$ ) of heattreatment during the in situ XRD measurement compared with that for films $(2 \mathrm{~h})$. Calcination at further elevated temperature (773 to $873 \mathrm{~K}$ ) reduced the intensity of $\mathrm{Nb}_{2} \mathrm{O}_{5}$ peaks for the film, while it enhanced them for powder; peaks $(2 \theta ; 46.0,50.0,55.0 \mathrm{deg})$ newly appeared. These facts suggest the partial decomposition of NESA layer occurring at the higher temperature. Thus, the $\mathrm{NbO}_{x}$ layer obtained by calcination at the lower temperature consists of amorphous oxide, and of crystalline $\mathrm{Nb}_{2} \mathrm{O}_{5}$ at the higher ( $\geqq 733 \mathrm{~K}$ ) temperature.

Such a structural change was followed by TG and DTA of $\mathrm{NbO}_{x}$ powders (Fig. 2). On heating up to $550 \mathrm{~K}$, the weight of the powdered $\mathrm{NbO}_{x}$ sample decreased to $\mathrm{ca} .81 \%$ of the original (a), accompanied by a significant endothermic DTA peak with the maximum at $c a .400 \mathrm{~K}$. The weight loss due to the elimination of water is most plausible. Subsequent heating up to $700 \mathrm{~K}$ induced negligible change in the weight of sample, suggesting the metastable structure of $\mathrm{NbO}_{x}$ in this temperature region (b). Further weight decrease was observed at around $750 \mathrm{~K}$. Characteristic exothermic peak appeared at $780 \mathrm{~K}$. Neither change in weight nor DTA shift was observed at the temperature region higher than $800 \mathrm{~K}$ (c). The total weight loss during the heating from room temperature to $1273 \mathrm{~K}$ was $24 \%$. On the assumptions that $\mathrm{NbO}_{x}$ consists of $\mathrm{Nb}_{2} \mathrm{O}_{5}$ and that only the dehydration causes the weight loss, the composition a of $\mathrm{Nb}_{2} \mathrm{O}_{5} \cdot 5 \mathrm{H}_{2} \mathrm{O}$ [or $\mathrm{Nb}(\mathrm{OH})_{5}$ ] and b of $\mathrm{Nb}_{2} \mathrm{O}_{5} \cdot \mathrm{H}_{2} \mathrm{O}$ [or $\mathrm{NbO}_{2}(\mathrm{OH})$ ] account for the results in TG. At present we have no experimental results to distinguish the hydrated oxides $\left(\mathrm{Nb}_{2} \mathrm{O}_{5} \cdot 5 \mathrm{H}_{2} \mathrm{O}\right.$ and $\left.\mathrm{Nb}_{2} \mathrm{O}_{5} \cdot \mathrm{H}_{2} \mathrm{O}\right)$ from the hydroxides $\left[\mathrm{Nb}(\mathrm{OH})_{5}\right.$ and $\left.\mathrm{NbO}_{2}(\mathrm{OH})\right]$. The $\mathrm{NbO}_{x}$ gel prepared from $\mathrm{Nb}(\mathrm{OPn})_{5}{ }^{14}$ showed a similar, but somewhat shifted (to higher temperature), DTA curve. However, the above-mentioned double-step TG curve is a unique characteristic of $\mathrm{NbO}_{x}$ sol from $\mathrm{Nb}(\mathrm{OEt})_{5}$; sharp decrease in weight could be seen between 473 and $523 \mathrm{~K}$ for the gel from $\mathrm{Nb}(\mathrm{OPn})_{5}$.

On the basis of the results of XRD, TG, and DTA, the structure of $\mathrm{NbO}_{x}$ could be described as follows. The asprepared gel (a) in a fully hydrated amorphous phase is dehydrated by the calcination at lower than $550 \mathrm{~K}$ into a metastable amorphous phase of partly hydrated oxide. Further dehydration into crystalline $\mathrm{Nb}_{2} \mathrm{O}_{5}$ proceeds at temperature higher than $700 \mathrm{~K}$. The exothermic peak in DTA at $780 \mathrm{~K}$ may correspond to the accompanying amorphous-crystal transition.

The $\mathrm{NbO}_{x}$ films were almost colorless and transparent. An example is shown in Fig. 3. This spectrum was recorded in transmission mode, not in reflection mode, and therefore included the concurrent absorption by a NESA glass substrate. The undulations seen in a whole range of spectrum are the interference pattern due to reflections of the front and back surfaces of the film. Difference in such optical characteristics due to the calcination temperature was not so marked. The films exhibited negligible change in these ultraviolet and visible range spectra by the contact with an aqueous formic acid solution $\left(9.0 \mathrm{~mol} \mathrm{dm}{ }^{-3}\right)$.

Cathodic polarization in acidic electrolyte induced the change in color. The $\mathrm{NbO}_{x}$ film turned brown or black and was bleached readily by anodic polarization. As Fig. 3 shows, an almost constant increase in absorption by cathodic polarization was observed in visible to the near infrared region. Thus, the thin films of $\mathrm{NbO}_{x}$ exhibited the EC activity. Early studies ${ }^{2.17}$ suggested that electrochromism of $\mathrm{Nb}_{2} \mathrm{O}_{5}$ is based on simultaneous injection of cations (proton, $\mathrm{H}^{+}$) and electrons, thereby reversible change occurs between $\mathrm{Nb}_{2} \mathrm{O}_{5}$ and $\mathrm{H}_{x} \mathrm{Nb}_{2} \mathrm{O}_{5}$. Although the color blue in the reduced form was reported previously, a somewhat different result was obtained in the present experiments. These facts might suggest a different morphology of $\mathrm{NbO}_{x}$ films related with the method of preparation.

Although the $\mathrm{NbO}_{x}$ film exhibited the above EC properties, unrelated with $T_{c}$, the degree of coloration under given conditions of cathodic polarization depended considerably on $T_{c}$ as shown in Fig. 4. The change in absorbance $(\triangle O D)$ by the cathodic polarization was monitored at $700 \mathrm{~nm}$ and plotted against $T_{\mathrm{c}}$. The as-prepared film $\left(T_{\mathrm{c}} 423 \mathrm{~K}\right)$ showed larger $\triangle O D$, which was reduced by elevating $T_{c}$ up to $700 \mathrm{~K}$. At $T_{\mathrm{c}}>700 \mathrm{~K}, \triangle O D$ was drastically enhanced to attain its maximum at $733 \mathrm{~K}$, and gradually decreased by the further calcination at higher $T_{\mathrm{c}}$. In several experiments of different potentials of cathodic polarization, similar dependences

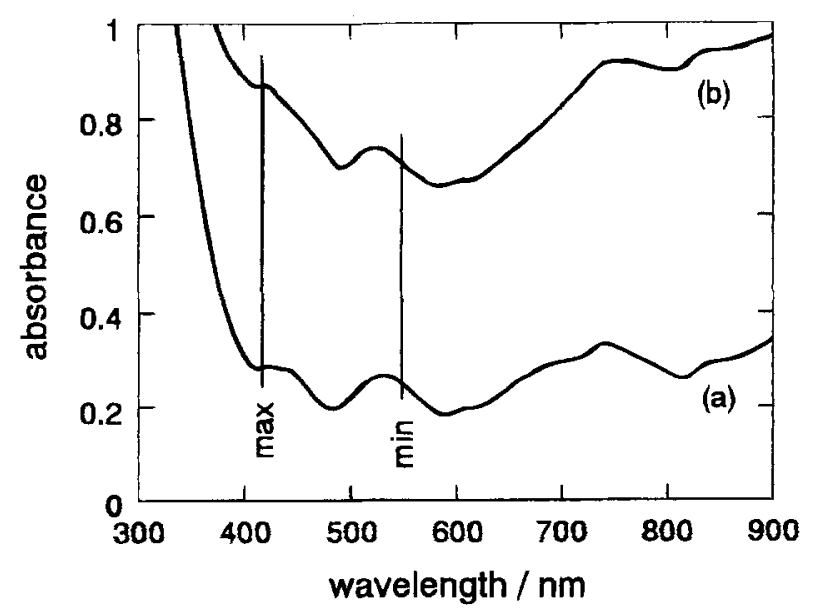

Fig. 3. Absorption spectra of $\mathrm{NbO}_{x}$-coated NESA glass (20/733) immersed in an aqueous formic acid solution $\left(1.0 \mathrm{~mol} \mathrm{dm}^{-3}\right)$, (a) before and (b) affer polarization at $-0.9 \mathrm{~V}$. 


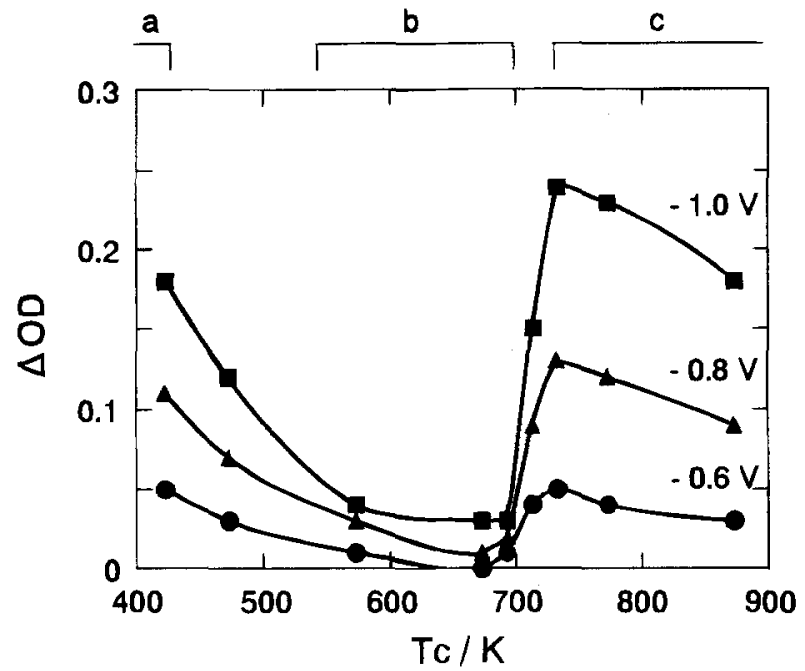

Fig. 4. Dependence on $T_{c}$ of $\triangle O D$ by cathodic polarization at given potentials for $20 \mathrm{~s}$ in $9.0 \mathrm{~mol} \mathrm{dm}$ aqueous formic acid solution.

were observed (Fig. 4). Comparison of these $T_{\mathrm{c}}$ dependents with the presumed structure of $\mathrm{NbO}_{x}$ indicates that the fully hydrated amorphous oxide (a) showed relatively higher EC property and it was reduced by dehydration into partly hydrated form (b). Further dehydration and crystallization (c) enhanced the EC property markedly. The lower EC property of the (b) state, assigned to be $\mathrm{Nb}_{2} \mathrm{O}_{5} \cdot \mathrm{H}_{2} \mathrm{O}$, should be correlated with its poor electronic and ionic conductivity. ${ }^{18}$

Figure 5 shows the variations of $\triangle O D$, current, and potential as a function of time during the repeated potential stepping at intervals of $20 \mathrm{~s}$ between -0.6 and $+1.0 \mathrm{~V}$. Reversible change in $\triangle O D$ was observed, and its maximum was kept almost constant during a few tenths of cycles. A relatively large cathodic current, which induces the coloration, was seen just after the step of potential to $-0.6 \mathrm{~V}$ and gradually decreased. Appreciable residual cathodic current flowed even at $20 \mathrm{~s}$ after the cathodic step. On the contrary, the decay of anodic current was rather sharp; both $\triangle O D$ and current became negligible within $5 \mathrm{~s}$. This behavior of cathodic and anodic currents seems to depend on neither the potential nor the concentration and kind of electrolytes (data not shown). Figure 6 shows relationship between $\triangle O D$ and passed charge, the latter of which was

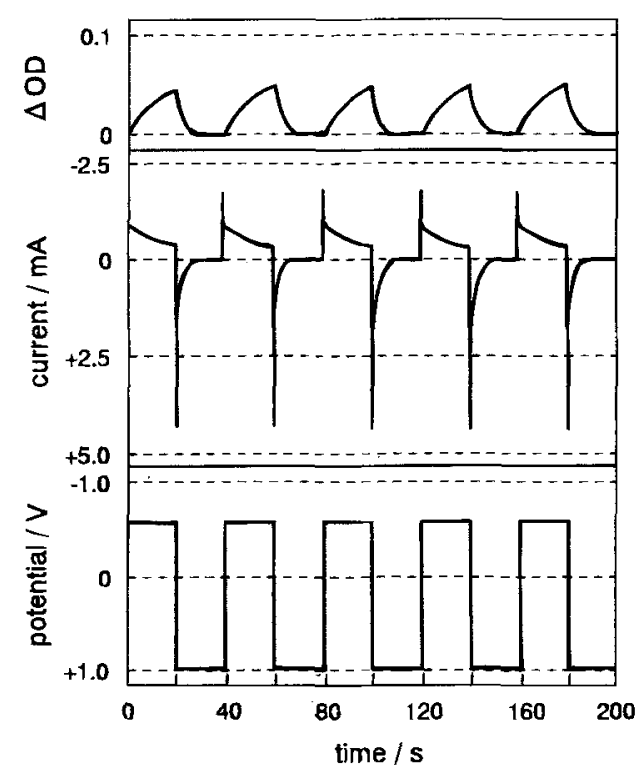

Fig. 5. Results of repeated potential stepping by every $20 \mathrm{~s}$ between -0.6 and $+1.0 \mathrm{~V}$ of $\mathrm{NbO}_{x}$ film $(10 / 733)$ immersed in $1.0 \mathrm{~mol}$ $\mathrm{dm}^{-3}$ aqueous formic acid solution.

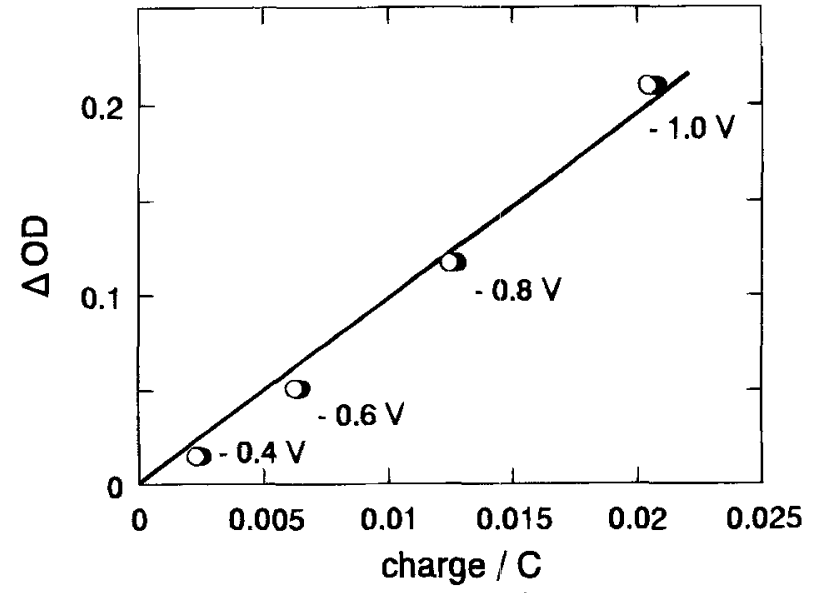

Fig. 6. Relationship between $\triangle O D$ and passed charge during coloration: $(O)$ figures denote the potential and $(0+1.0 \mathrm{~V})$ bleaching processes of $10 / 733$ film immersed in a $1.0 \mathrm{~mol} \mathrm{dm}^{-3}$ aqueous formic acid solution.

calculated by integration of the current profile, for both cathodic (coloration) and anodic (bleaching) processes. The linear relation for both processes at various cathodic potential clearly shows that the EC property of the present $\mathrm{NbO}_{x}$ films is attributed to a unique reversible electrochemical reaction. From the slope of the linear plot, $\triangle O D$ per unit charge density, corresponding to efficiency of coloring, is estimated to be $38 \mathrm{C}^{-1} \mathrm{~cm}^{2}$ (at $700 \mathrm{~nm}$ ). This coulombic efficiency is superior to that reported for $\mathrm{Nb}_{2} \mathrm{O}_{5}$ thin film via the sol-gel process $\left(6 \mathrm{C}^{-1} \mathrm{~cm}^{2} \text { at } 800 \mathrm{~nm}\right)^{9}$ and sputtering $\left(<10 \mathrm{C}^{-1} \mathrm{~cm}^{2}\right),{ }^{19}$ However, the efficiency is $\mathrm{c} a$. four times smaller than that for a $\mathrm{WO}_{3}$ film prepared by sol-gel process $\left(167 \mathrm{C}^{-1} \mathrm{~cm}^{2}\right.$ at $\left.800 \mathrm{~nm}\right){ }^{10}$

Stability of $\mathrm{NbO}_{x}$ films was studied in prolonged periods as shown in Fig. 7. In these experiments, the duration of anodic potential $(+1.0 \mathrm{~V})$ step was expanded to $180 \mathrm{~s}$ to bleach completely. In the experiment with the duration of a given cathodic potential $(-1.2 \mathrm{~V})$ for $40 \mathrm{~s}$, the maximum $\triangle O D$ after the 104th cycle was considerably decreased

(a)

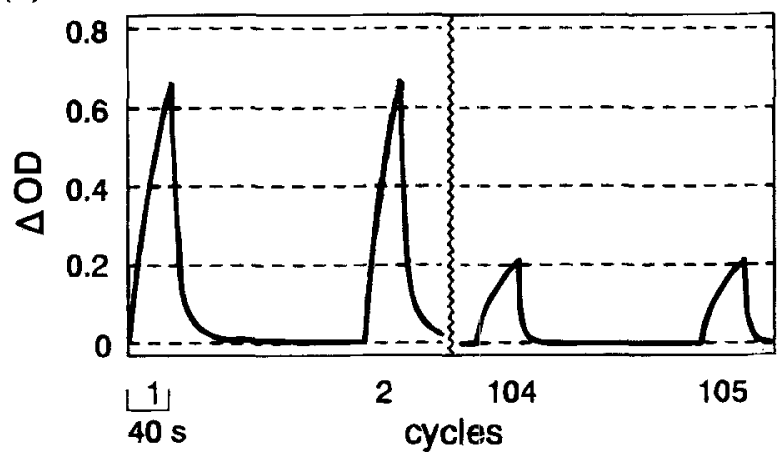

(b)

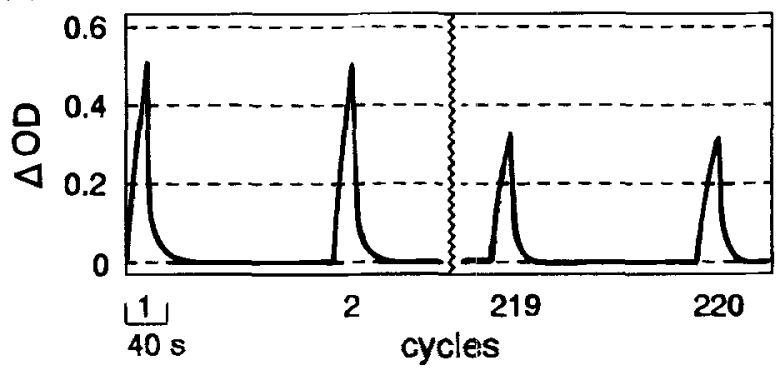

Fig. 7. Parts of time course of $\triangle O D$ of $30 / 733 \mathrm{film}$ in repeated polarization $[-1.2 \mathrm{~V}$ for $(\mathrm{a}) 40 \mathrm{~s}$ and (b) $20 \mathrm{~s}$ and $+1.0 \mathrm{~V}$ for $180 \mathrm{~s}]$ in $1.0 \mathrm{~mol} \mathrm{dm}^{-3}$ aqueous formic acid solution. 
(a)

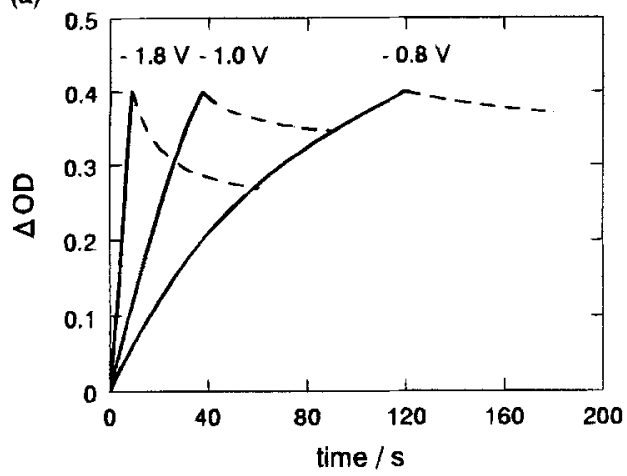

(b)

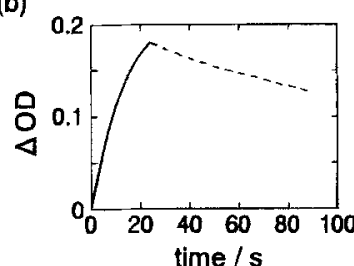

Fig. 8. Memory characteristics of $30 / 733$ film immersed in (a) $1.0 \mathrm{~mol} \mathrm{dm}$ aqueous formic acid and (b) $0.1 \mathrm{~mol} \mathrm{dm}^{-3}$ acetonitrile solution of lithium fluoroborate. In the experiment in aqueous electrolyte (a), the film was cathodically polarized (solid lines) to attain $\triangle O D 0.4$, and the circuit was opened (dashed lines).

( $29 \%$ of the original). It should be noted that the current profile (data not shown) remained almost unchanged after such prolonged experiments. As a result, the efficiency of coloring was ca. $25 \%$ of the original $\left(35\right.$ to $\left.8.7 \mathrm{C}^{-1} \mathrm{~cm}^{2}\right)$. On the other hand, reduction of cathodic duration to $20 \mathrm{~s} \mathrm{im-}$ proved the stability of $\mathrm{NbO}_{x}$ film, though the maximum $\triangle O D$ was a little decreased in the first stage of experiments. Even after the 219 th cycle, $67 \%$ of $\triangle O D$ could be obtained. Also in this case, the current profile was kept almost constant, and the coloring efficiency was in proportion to $\triangle O D$ [ca. $68 \%\left(36 \mathrm{C}^{-1} \mathrm{~cm}^{2}\right)$ after 219 cycles; in the first cycle, $\left.53 \mathrm{C}^{-1} \mathrm{~cm}^{2}\right]$. The reason for such decrease in the coloring efficiency is ambiguous at present. As a possibility, it is assumed that certain structural changes are induced during the repeated alternating polarization cycles to enhance the hydrogen $\left(\mathrm{H}_{2}\right)$ liberation rather than the coloration, though we have at present no experimental evidence for this. Further assumption that the longer the cathodic polarization the more the structure changes is consistent with the fact that durability under $40 \mathrm{~s}$ cathodic duration is inferior to that under $20 \mathrm{~s}$ duration, as described above.

Memory characteristics of once-colored $\mathrm{NbO}_{x}$ films under open-circuit conditions were examined (Fig. 8); the film was cathodically polarized to attain prescribed $\triangle O D(0.4)$ and time dependence of $\triangle O D$ was measured thereafter. As clearly seen in Fig. 8, bleaching proceeded spontaneously without the flow of the current through the electrode. Such phenomenon of the spontaneous bleaching has been reported for $\mathrm{Nb}_{2} \mathrm{O}_{5}$ films prepared by anodization ${ }^{6}$ and thermal oxidation. ${ }^{4}$ In these reports, the phenomenon has been interpreted in terms of oxidation of the reduced moiety $\left(\mathrm{H}_{x} \mathrm{Nb}_{2} \mathrm{O}_{5}\right)$ by oxygen dissolved in the electrolyte or by water in the film. In this relation, Mohapatra ${ }^{20}$ reported that memory characteristics of $\mathrm{WO}_{3}$ thin film could be improved by using argon-saturated cell instead of oxygen-saturated one and by replacement of aqueous electrolyte by aprotic organic solvent containing lithium salt. However, in our experiment, a negligible effect of nitrogen bubbling could be seen. Furthermore, the use of acetonitrile solution of 0.1 mol dm $\mathrm{dm}^{-3}$ lithium fluoroborate was also unsuccessful for eliminating spontaneous bleaching (Fig. 8). It is noticeable that the rate of bleaching depends strongly on the preceding cathodic potential which determines the rate of coloration. The faster the cathodic coloring, the faster the color bleached; the decrease in $\triangle O D$ of $\mathrm{NbO}_{x}$ film colored at the potential of $-0.8 \mathrm{~V}$ was negligibly small. On the assumption that the $\mathrm{EC}$ properties of $\mathrm{NbO}_{x}$ in the present study are also based on the reversible electrochemical reaction between $\mathrm{Nb}_{2} \mathrm{O}_{5}$ and $\mathrm{H}_{x} \mathrm{Nb}_{2} \mathrm{O}_{5}$, the spontaneous bleaching under open-circuit conditions should be caused by the oxidation of $\mathrm{H}_{x} \mathrm{Nb}_{2} \mathrm{O}_{5}$. The reason for its dependence on the preceding cathodic potential is unknown at present. However, it is possible to assume that difference in distribution, i.e., depth profile of reduced moiety $\left(\mathrm{H}_{x} \mathrm{Nb}_{2} \mathrm{O}_{5}\right)$, depending on the cathodic potential, gives considerable influence on the oxidation of $\mathrm{H}_{x} \mathrm{Nb}_{2} \mathrm{O}_{5}$. Research along this line is now in progress.

\section{Conclusion}

Thin film of $\mathrm{NbO}_{x}$ was prepared on NESA glass substrates by the sol-gel process. The optimum EC properties were obtained for the film consisting of crystalline $\mathrm{Nb}_{2} \mathrm{O}_{5}$. Its stability in repeated polarization cycles depended on the cathodic polarization time. The $\mathrm{NbO}_{x}$ films prepared by the sol-gel process in this work have higher coulombic efficiency than the other $\mathrm{NbO}_{x}$ films in previous reports. However, the spontaneous bleaching proceeds under open-circuit conditions. Clarification of the reason for this poor memory characteristic and improvements are necessary for the practical use of this $\mathrm{NbO}_{x}$ film as the electrochromic material.

\section{Acknowledgment}

The authors indebted to Mr. Masaya Chigane (Osaka Municipal Technical Research Institute) for his cooperation in XRD measurements. Dr. Hiroaki Tada (Nippon Sheet Glass Co. Ltd.) is greatly acknowledged for the supply of NESA glass substrates.

Manuscript submitted Nov. 29, 1993; revised manuscript received May 2, 1994

Kyoto University assisted in meeting the publication costs of this article.

\section{REFERENCES}

1. C. G. Granqvist, Solid State Ionics, 53-56, 479 (1992).

2. B. Reichman and A. J. Bard, This Journal, 127, 241 (1980).

3. N. Kumagai, K. Tanno, T. Nakajima, and N. Watanabe, Electrochim. Acta, 28, 17 (1983).

4. R. Cabanel, J. Chaussy, J. Mazuer, G. Delabouglise, J. C. Joubert, G. Barral, and C. Montella, This Journal, 137, 1444 (1990).

5. M. A. B. Gomes, L. O. de S. Bulhoes, S. C. de Castro, and A. J. Damiao, ibid., 137, 3067 (1990).

6. C. K. Dyer and J. S. L. Leach, ibid., 125, 23 (1978)

7. N. Machida, M. Tatsumisago, and T. Minami, ibid., 133, $1963(1986)$.

8. J. N. Yao, B. H. Loo, K. Hashimoto, and A. Fujishima, Ber. Bunsenges. Phys. Chem., 96, 699 (1992).

9. G. R. Lee and J. A. Crayston, J. Mater. Chem., 1, 381 (1991).

10. B. Ohtani, M. Masuoka, T. Atsumi, S. Nishimoto, and T Kagiya, Chem. Express, 3, 319 (1988)

11. B. Ohtani, N. Kato, S. Nishimoto, and T. Kagiya, Denki Kagaku oyobi Kogyo Buturi Kagaku, 57,1112 (1989).

12. B. Ohtani, T. Atsumi, S. Nishimoto, and T. Kagiya, Chem. Lett., 295 (1988).

13. F. Goetti-Bianchini, M. Guglielmi', P. Polato, and G. D. Soraru, J. Non-Cryst. Solids, 63, 251 (1984).

14. P. Griesmar, G. Papin, C. Sanchez, and J. Livage, Chem. Mater., 3, 335 (1991).

15. M. Chigane and M. Ishikawa, J. Chem. Soc., Faraday Trans., 88, 2303 (1992).

16. Joint Committee on Powder Diffraction Standards, Powder Diffraction File, Set 28, No. 317, Swarthmore, PA (1974).

17. C. M. Lampert, Solar Energy Mater., 11, 1 (1984).

18. C. E. Rice and J. L. Jackel, J. Solid State Chem., 41, 308 (1982).

19. R. D. Rauh and S. F. Cogan, Solid State Ionics, 28-30, 1707 (1988).

20. S. K. Mohapatra, This Journal, 125, 284 (1978). 